Article

\title{
Essential Oils from Leaves of Medicinal Plants of Brazilian Flora: Chemical Composition and Activity against Candida Species
}

\author{
Maria da Conceição Mendes Ferreira da Costa ${ }^{1}$, Alexandre Gomes da Silva ${ }^{2}$, \\ Ana Paula Sant'Anna da Silva ${ }^{1}$, Vera Lúcia de Menezes Lima ${ }^{1}$, Patrícia Cristina Bezerra-Silva ${ }^{3}$, \\ Suyana Karolyne Lino da Rocha ${ }^{3}$, Daniela Maria do Amaral Ferraz Navarro ${ }^{3}$, \\ Maria Tereza dos Santos Correia ${ }^{1}$, Thiago Henrique Napoleão ${ }^{1}$, Márcia Vanusa da Silva ${ }^{1}$ and \\ Patrícia Maria Guedes Paiva ${ }^{1, *}$ \\ 1 Departamento de Bioquímica, Centro de Biociências, Universidade Federal de Pernambuco, \\ Cidade Universitária, Recife 50670-420, Pernambuco, Brazil; ceacosta.ufpe@gmail.com (M.C.M.F.C.); \\ annapsantanna@hotmail.com (A.P.S.S.); vlml@ufpe.br (V.L.M.L.); mtscorreia@gmail.com (M.T.S.C.); \\ thiagohn86@yahoo.com.br (T.H.N.); marciavanusa@yahoo.com.br (M.V.S.) \\ 2 Instituto Nacional do Semiárido, Campina Grande 58429-970, Paraíba, Brazil; agsilva@live.com \\ 3 Departamento de Química Fundamental, Centro de Ciências Exatas e da Natureza, Universidade Federal de \\ Pernambuco, Recife 50670-901, Pernambuco, Brazil; patricia.c.bezerra@hotmail.com (P.C.B.-S.); \\ suyanarocha@hotmail.com (S.K.L.R.); navarrix@uol.com.br (D.M.A.F.N.) \\ * Correspondence: ppaivaufpe@yahoo.com.br; Tel.: +55-81-2126-8540
}

Academic Editor: Eleni Skaltsa

Received: 14 March 2017; Accepted: 28 April 2017; Published: 3 May 2017

\begin{abstract}
Background: The biotechnological potential of medicinal plants from Brazilian Caatinga and the Atlantic Forest has not been extensively studied. Thus, screening programs are important in prospecting for compounds for developing new drugs. The purpose of this study was to determine the chemical composition and to evaluate the anti-Candida activity of essential oils from leaves of Hymenaea courbaril var. courbaril, Myroxylon peruiferum, and Vismia guianensis. Methods: The oils were extracted through hydrodistillation and their chemical compositions were analyzed by gas chromatography coupled with mass spectrometry. Antifungal activity against $C$. albicans, $C$. tropicalis, C. parapsilosis, C. glabrata, and C. krusei was evaluated by determining the minimal inhibitory (MIC) and fungicidal (MFC) concentrations. Results: The major compounds of the oils were caryophyllene oxide and trans-caryophyllene for $H$. courbaril; spathulenol, $\alpha$-pinene, and caryophyllene oxide for M. peruiferum; and caryophyllene oxide and humulene epoxide II for V. guianensis oil. The oils showed antifungal activity against all the strains tested, and the MIC values ranged between 0.625 and $1.25 \mu \mathrm{L} / \mathrm{mL}$ and MFC from 0.625 to $2.5 \mu \mathrm{L} / \mathrm{mL}$. Conclusion: The essential oils from the species studied have the potential to be evaluated as clinical applications in the treatment of candidiasis.
\end{abstract}

Keywords: essential oils; antifungal activity; Brazilian flora; Fabaceae; Hypericaceae

\section{Introduction}

Candidiasis is the most frequent infection caused by opportunistic fungi, with a very extensive spectrum ranging from mild manifestations (e.g., a colonization of mucosal tissues) to systemic infections with the invasion of different organs [1]. Candida albicans is the most common causative agent in humans, but the species Candida tropicalis, Candida parapsilosis, Candida glabrata, and Candida krusei are also commonly associated with serious infections [2-4]. In addition, C. glabrata and C. krusei are described as having intrinsic resistance to some of the more conventional antifungal drugs $[5,6]$. 
Azole antifungal agents are the most used in therapeutic regimens for the treatment of candidiasis. However, these antibiotics are not always successful because of the significant incidence of microorganism resistance [7]. This has stimulated the search for new antifungal agents in order to increase the number of alternatives to treat infections and minimize the impact of resistance.

Natural products have been traditionally used to treat many diseases, including fungal infections, and plant compounds have been explored by the pharmaceutical industry for use as antimicrobial agents or as models for the synthesis of new drugs [8]. Essential oils, which consist in liquid, are volatile, and are rarely colored mixtures of compounds soluble in organic solvents, are among these potential alternatives $[9,10]$. The essential oils are usually constituted by some components at high concentrations $(20-70 \%)$, being deemed majoritary compounds, while the other components are present in trace amounts [11].

Plants from Caatinga and Atlantic Forest have also been used to obtain natural medicines by Brazilian local populations [12]. However, despite the rich flora of these biomes, the biotechnological potential of plants as sources of antifungal agents has not been extensively studied. Thus, screening programs are very important in order to prospect for compounds for developing new antimicrobial drugs.

This study was conducted with essential oils from three medicinal plants of Brazilian flora. Hymenaea courbaril var. courbaril (Fabaceae) has a broad distribution being found in Brazil at Atlantic and Amazon Forests, Caatinga, Cerrado, and Pantanal. It has several medicinal uses; for example, the stem bark decoction or syrup can be used against coughs and anemia, and leaf infusion can be used against urinary tract disorders [13,14]. Myroxylon peruiferum (Fabaceae) is found at the Brazilian Atlantic Forest and Cerrado and has heavy wood that is resistant to deterioration. Its bark is used as an anti-inflammatory, and the fruits are used to alleviate earache $[15,16]$. The leaves of Vismia guianensis (Hypericaceae) are used against problems in spine and kidneys as well as to alleviate pains in general [17]. This plant can be found in the Amazon and Atlantic Forests [13].

The aim of this work was to determine the chemical composition of essential oils from leaves of $H$. courbaril var. courbaril, M. peruiferum, and V. guianensis and to evaluate the antifungal activity of them against Candida species.

\section{Materials and Methods}

\subsection{Plant Materials}

Leaves of $V$. guianensis were collected in December 2012, at the nature reserve of Camaçari $\left(8^{\circ} 16^{\prime} 23^{\prime \prime} \mathrm{S}, 34^{\circ} 57^{\prime} 45^{\prime \prime} \mathrm{W}\right)$ at Cabo de Santo Agostinho, Pernambuco, Brazil, at an Atlantic Forest region. Leaves of H. courbaril var. courbaril and M. peruiferum were collected in March 2013 at the Vale do Catimbau National Park $\left(08^{\circ} 30^{\prime} 02.3^{\prime \prime}\right.$ S, $37^{\circ} 20^{\prime} 31^{\prime \prime}$ W) in Pernambuco, Brazil, at a Caatinga region. For each plant, leaves were collected from at least 15 individuals and pooled for oil extraction. Plant collection was performed with authorization (number 16806) of the Instituto Chico Mendes de Conservação da Biodiversidade (ICMBio). Voucher specimens of $H$. courbaril var. courbaril (number 84888), M. peruiferum (number 84110), and V. guianensis (number 90471) are deposited in the herbarium "Dárdano de Andrade Lima" from the Instituto Agronômico de Pernambuco, Recife, Brazil. The leaves were dried at $28^{\circ} \mathrm{C}$, milled to a fine powder, and used immediately for the extraction of oils.

\subsection{Extraction of Essential Oils}

The powders of leaves were separately submitted to hydrodistillation in a Clevenger-type apparatus for $4 \mathrm{~h}$. The essential oils obtained were then dried over an anhydrous sodium sulfate and stored in sealed vials protected from the light at $-20^{\circ} \mathrm{C}$. The essential oil emulsions used in antifungal assays were prepared as follows: $400 \mu \mathrm{L}$ of essential oil plus $40 \mu \mathrm{L}$ of Tween 80 and $4.56 \mathrm{~mL}$ of sterile distilled water were combined and shaken for 5 min using a vortex, obtaining emulsions with a final concentration of $80 \mu \mathrm{L} / \mathrm{mL}$. 


\subsection{Chromatography Analyses}

Gas chromatography (GC) analyses were performed in order to determine the relative proportions of the components of the oils. GC analyses were carried on a Thermo TraceGC Ultra (Thermo Scientific, Milan, Italy) equipped with a flame ionization detector (FID) (Thermo Scientific, Milan, Italy) and a VB-5 fused silica capillary column (ValcoBond $30 \mathrm{~m} \times 0.25 \mathrm{~mm}$ i.d.; film thickness: $0.25 \mathrm{~mm}$ ) (Valco Instruments Company Inc. , Houston, TX, USA). Nitrogen was employed as a carrier gas at a flow rate of $1 \mathrm{~L} / \mathrm{min}$ and $30 \mathrm{psi}$ inlet pressure. The oven temperature program was initially $40{ }^{\circ} \mathrm{C}$, was held for $2 \mathrm{~min}$, was increased to $230^{\circ} \mathrm{C}$ at $4{ }^{\circ} \mathrm{C} / \mathrm{min}$, and was then held for $5 \mathrm{~min}$. The injector and detector temperatures were set to $250{ }^{\circ} \mathrm{C}$ and $280{ }^{\circ} \mathrm{C}$, respectively. The sample $(1 \mu \mathrm{L} ; 2 \mathrm{mg} / \mathrm{mL}$ in n-hexane) was injected splitless. The relative amount of each component was estimated from the corresponding peak area and expressed as a percentage of the total area of the chromatogram. Analyses were carried out in triplicate.

The identification of the compounds present in the oils was performed by GC coupled with mass spectrometry (GC-MS). These analyses were carried out using an Agilent 5975C Series GC/MSD (Agilent Technologies, Palo Alto, CA, USA) quadrupole instrument equipped with an Agilent J\&W non-polar DB-5 fused silica capillary column $(30 \mathrm{~m} \times 0.25 \mathrm{~mm}$ i.d.; film thickness: $0.25 \mu \mathrm{m}$ ) (Agilent Technologies, Palo Alto, CA, USA). For each sample, $1 \mu \mathrm{L}$ was injected in split mode (50:1) with the injector temperature set to $250{ }^{\circ} \mathrm{C}$. GC oven temperature was set to $40{ }^{\circ} \mathrm{C}$, was held for $2 \mathrm{~min}$, was increased to $230{ }^{\circ} \mathrm{C}$ at $4{ }^{\circ} \mathrm{C} / \mathrm{min}$, and was then held for $5 \mathrm{~min}$. Helium (He) was used as a carrier gas at a flow of $1 \mathrm{~mL} / \mathrm{min}$, maintained at a constant pressure of $7.0 \mathrm{psi}$. MS Source and quadrupole temperatures were set to $230^{\circ} \mathrm{C}$ and $150{ }^{\circ} \mathrm{C}$, respectively. Mass spectra were taken at $70 \mathrm{eV}$ (in EI mode) with a scanning speed of 1.0 scans from $m / z$ 35-350. The identification of the individual components was carried out by comparison with previously reported values of retention indices, obtained by co-injection of oil samples and a set of $\mathrm{C}_{9}-\mathrm{C}_{30}$ linear hydrocarbons, and calculated according to the equation of Van den Dool and Kratz [18]. Subsequently, the MS data acquired for each component were matched with the data available in the mass spectral library of the GC-MS system (MassFinder 4, Dr. Hochmuth scientific consulting, Hamburg, Germany); NIST08 Mass Spectral Library (ChemSW Inc. Fairfield, CA, USA); Wiley Registry ${ }^{\mathrm{TM}}$ of Mass Spectral Data 9th Edition (Wiley, Hoboken, NJ, USA) and with other published mass spectral data [19]. Analyses were carried out in triplicate.

\subsection{Antifungal Assays}

Strains of C. tropicalis (URM-6741), C. krusei (URM-6391), C. albicans (URM-6543), C. parapsilosis (URM-6557), and C. glabrata (URM-6393) were obtained from the University Recife Mycologia (URM) from the Departamento de Micologia of Universidade Federal de Pernambuco. The yeasts were grown overnight at $30^{\circ} \mathrm{C}$ in Petri plates containing Sabouraud dextrose agar (Merck, Darmstadt, Germany), and inocula for use in the assays were prepared by diluting scraped cell mass in $0.85 \% \mathrm{NaCl}$, adjusting to 0.5 in McFarland. Cell suspensions were finally diluted to $10^{6} \mathrm{CFU} / \mathrm{mL}$ for use in the assays.

The minimal inhibitory concentrations (MICs) of the essential oils were determined through the microdilution technique. Firstly, $100 \mu \mathrm{L}$ of Sabouraud dextrose broth (Merck, Darmstadt, Germany) were taken into the wells of a 96-well microtiter plate. The first well of each row was used as a sterility control and contained only culture medium. Next, $100 \mu \mathrm{L}$ of the emulsion of oil emulsion $(80 \mu \mathrm{L} / \mathrm{mL})$ were placed in the second well of a row and two-fold serial dilution was then performed until a concentration of $0.04 \mu \mathrm{L} / \mathrm{mL}$ was reached. In each well, aliquots of $10 \mu \mathrm{L}$ of the microorganism inoculum were dispensed. In parallel, a negative control containing only microorganism and medium was run to assure the viability of the yeast strains. It was also performed a positive control using the antifungal fluconazole (Sigma-Aldrich, St. Louis, MO, USA). Assays were performed in triplicate and plates were incubated at $30^{\circ} \mathrm{C}$ for $48 \mathrm{~h}$. After this period, $10 \mu \mathrm{L}$ of the dye 2,3,5-triphenyl tetrazolium chloride $(0.5 \%, w / v)$ was added in each well to detect bacterial growth. The MIC was defined as the lowest oil concentration that promoted inhibition of yeast growth. 
After the determination of the MIC, aliquots from the wells where there was growth inhibition, as well as from positive and negative controls, were subcultured on Petri plates containing Sabouraud dextrose agar (Merck). After $24 \mathrm{~h}$ at $30{ }^{\circ} \mathrm{C}$, the microbial growth was observed and the number of CFU was counted. The minimal fungicide concentration (MFC) was defined as the lowest oil concentration that reduced the number of $\mathrm{CFU}$ in $99.9 \%$ in comparison with the initial inoculum.

According to the MFC/MIC ratio, the antifungal activity was classified as follows: if $\mathrm{MFC} / \mathrm{MIC}=1$ or 2, the effect was considered fungicidal; if $\mathrm{MFC} / \mathrm{MIC} \geq 4$, the effect was defined as fungistatic.

\section{Results}

The yields of oil extraction were $0.975 \%, 0.276 \%$, and $0.306 \%$ for H. courbaril, M. peruiferum, and $V$. guianensis, respectively. The chemical composition of the essential oils can be seen in Table 1. A total of 62 compounds were identified in the essential oils. The oils of the species H. courbaril, M. peruiferum, and $V$. guianensis were rich in mono and sesquiterpenes. The trans-caryophyllene, $\delta$-cadinene and caryophyllene oxide were present in all the three oils.

Table 1. Identification of constituents of the essential oil from leaves of Hymenaea courbaril var. courbaril (HC), Myroxylon peruiferum (MP), and Vismia guianensis (VG).

\begin{tabular}{|c|c|c|c|c|c|}
\hline \multirow{2}{*}{ Compound $^{\text {a }}$} & \multicolumn{2}{|c|}{ Retention Index } & \multicolumn{3}{|c|}{ Content (as $\%$ of Total Oil) + SD } \\
\hline & Determined $^{b}$ & Literature $^{\mathrm{c}}$ & HC & MP & VG \\
\hline$\alpha$-Pinene & 932 & 932 & - & $9.64 \pm 0.20$ & - \\
\hline Thuja-2,4 (10)-diene & 952 & 953 & - & $0.23 \pm 0.01$ & - \\
\hline$\beta$-Pinene & 974 & 974 & - & $0.44 \pm 0.01$ & - \\
\hline Myrcene & 991 & 988 & - & $0.15 \pm 0.03$ & - \\
\hline$\rho$-Cymene & 1024 & 1020 & - & $0.10 \pm 0.04$ & - \\
\hline Limonene & 1028 & 1024 & - & $7.17 \pm 0.38$ & - \\
\hline$\gamma$-Terpinene & 1058 & 1054 & - & $0.12 \pm 0.07$ & - \\
\hline Terpinolene & 1088 & 1086 & - & $0.05 \pm 0.02$ & - \\
\hline$\alpha$-Campholenal & 1126 & 1122 & - & $0.95 \pm 0.04$ & - \\
\hline trans-Pinocarveol & 1138 & 1135 & - & $0.38 \pm 0.06$ & - \\
\hline trans-Verbenol & 1144 & 1140 & - & $1.17 \pm 0.15$ & - \\
\hline Citronellal & 1154 & 1148 & - & - & $0.19 \pm 0.01$ \\
\hline Pinocarvone & 1163 & 1160 & - & $0.08 \pm 0.05$ & - \\
\hline$\alpha$-Phellandre-8-ol & 1167 & 1166 & - & $0.20 \pm 0.00$ & - \\
\hline Terpinen-4-ol & 1177 & 1174 & - & $0.41 \pm 0.01$ & - \\
\hline trans-Carveol & 1219 & 1215 & - & $0.22 \pm 0.01$ & - \\
\hline Isovaleric acid & 1234 & 1232 & - & $0.22 \pm 0.01$ & - \\
\hline$\alpha$-Cubebene & 1351 & 1348 & $0.72 \pm 0.08$ & $1.19 \pm 0.01$ & $0.23 \pm 0.02$ \\
\hline$\alpha$-Ylangene & 1373 & 1373 & - & - & $0.18 \pm 0.01$ \\
\hline$\alpha$-Copaene & 1377 & 1374 & $1.95 \pm 0.16$ & $2.63 \pm 0.11$ & $3.35 \pm 0.17$ \\
\hline$\beta$-Bourbonene & 1387 & 1387 & - & $4.96 \pm 0.21$ & - \\
\hline$\beta$-Cubebene & 1392 & 1387 & - & $0.66 \pm 0.02$ & - \\
\hline$\beta$-Elemene & 1393 & 1389 & $1.49 \pm 0.07$ & $6.79 \pm 0.20$ & $0.34 \pm 0.06$ \\
\hline Cyperene & 1401 & 1398 & $2.28 \pm 0.20$ & - & - \\
\hline Ylanga-2,4 (15)-diene & 1407 & $1400^{\mathrm{d}}$ & - & $0.55 \pm 0.03$ & - \\
\hline trans-Caryophyllene & 1421 & 1417 & $18.80 \pm 0.10$ & $3.51 \pm 0.11$ & $3.18 \pm 0.17$ \\
\hline$\beta$-Copaene & 1431 & 1430 & $0.56 \pm 0.08$ & - & $0.54 \pm 0.04$ \\
\hline trans- $\alpha$-Bergamotene & 1437 & 1432 & $0.60 \pm 0.09$ & - & - \\
\hline Aromadendrene & 1441 & 1439 & $0.27 \pm 0.04$ & - & - \\
\hline$\alpha$-Humulene & 1456 & 1452 & $2.89 \pm 0.06$ & $1.19 \pm 0.06$ & $1.09 \pm 0.06$ \\
\hline Caryophyllene<9-epi-(E)-> & 1464 & 1464 & - & $0.22 \pm 0.00$ & - \\
\hline$\gamma$-Muurolene & 1479 & 1478 & $0.51 \pm 0.06$ & $0.42 \pm 0.02$ & $2.98 \pm 0.35$ \\
\hline Germacrene D & 1486 & 1484 & $2.12 \pm 0.16$ & $1.06 \pm 0.04$ & - \\
\hline$\beta$-Selinene & 1489 & 1489 & $1.99 \pm 0.33$ & $1.63 \pm 0.04$ & $0.62 \pm 0.04$ \\
\hline Viridiflorene & 1497 & 1496 & - & - & $0.33 \pm 0.02$ \\
\hline$\alpha$-Selinene & 1498 & 1498 & $3.12 \pm 0.32$ & $1.22 \pm 0.03$ & - \\
\hline Bicyclogermacrene & 1499 & 1500 & - & $5.49 \pm 0.20$ & - \\
\hline trans- $\beta$-Guaiene & 1503 & 1502 & $1.20 \pm 0.08$ & - & - \\
\hline$\alpha$-Muurolene & 1503 & 1500 & - & $4.23 \pm 0.50$ & $0.55 \pm 0.04$ \\
\hline Germacrene A & 1508 & 1508 & - & $2.67 \pm 0.08$ & - \\
\hline$\gamma$-Cadinene & 1517 & 1513 & $0.63 \pm 0.18$ & $0.83 \pm 0.02$ & $2.03 \pm 0.118$ \\
\hline$\delta$-Cadinene & 1525 & 1522 & $1.16 \pm 0.10$ & $2.84 \pm 0.02$ & $0.96 \pm 0.08$ \\
\hline trans-Cadina-1,4-diene & 1535 & 1533 & - & $0.18 \pm 0.02$ & - \\
\hline$\alpha$-Cadinene & 1540 & 1537 & - & $0.13 \pm 0.08$ & $0.31 \pm 0.05$ \\
\hline Unidentified Sesquiterpene & 1544 & - & - & - & $0.86 \pm 0.05$ \\
\hline$\alpha$-Calacorene & 1546 & 1544 & $2.90 \pm 0.05$ & $0.37 \pm 0.01$ & - \\
\hline
\end{tabular}


Table 1. Cont.

\begin{tabular}{|c|c|c|c|c|c|}
\hline \multirow{2}{*}{ Compound ${ }^{a}$} & \multicolumn{2}{|c|}{ Retention Index } & \multicolumn{3}{|c|}{ Content (as \% of Total Oil) + SD } \\
\hline & Determined $^{b}$ & Literature $^{c}$ & $\mathrm{HC}$ & MP & VG \\
\hline Unidentified Sesquiterpene & 1555 & - & $0.23 \pm 0.05$ & $0.79 \pm 0.01$ & $2.54 \pm 0.11$ \\
\hline Unidentified compound & 1562 & - & - & - & $0.61 \pm 0.02$ \\
\hline trans-Nerolidol & 1565 & 1561 & $1.09 \pm 0.18$ & - & $0.64 \pm 0.04$ \\
\hline Unidentified Sesquiterpene & 1569 & - & $1.38 \pm 0.11$ & - & - \\
\hline Spathulenol & 1581 & 1577 & $0.41 \pm 0.06$ & $13.29 \pm 0.48$ & $0.74 \pm 0.03$ \\
\hline Caryophyllene oxide & 1586 & 1582 & $29.55 \pm 1.32$ & $7.27 \pm 0.27$ & $46.8 \pm 1.75$ \\
\hline Salvial-4 (14)-em-1-one & 1597 & 1594 & $0.46 \pm 0.02$ & $0.96 \pm 0.05$ & $1.12 \pm 0.02$ \\
\hline Unidentified Sesquiterpene & 1602 & - & - & - & $0.94 \pm 0.06$ \\
\hline Unidentified Sesquiterpene & 1607 & - & - & - & $0.55 \pm 0.10$ \\
\hline Humulene epoxide II & 1612 & 1608 & $2.80 \pm 0.12$ & - & $7.21 \pm 0.05$ \\
\hline Unidentified Sesquiterpene & 1628 & - & $15.62 \pm 0.32$ & - & $0.19 \pm 0.11$ \\
\hline Cubenol $<1$-epi-> & 1631 & 1627 & $0.51 \pm 0.09$ & $0.15 \pm 0.01$ & $1.73 \pm 0.18$ \\
\hline Unidentified Sesquiterpene & 1635 & - & - & - & $1.45 \pm 0.18$ \\
\hline Caryophylla-4 (12),8 (13)-dien-5-ol & 1639 & 1639 & $0.34 \pm 0.05$ & - & $0.84 \pm 0.40$ \\
\hline$\tau$-Muurolol & 1645 & 1640 & $0.50 \pm 0.20$ & $0.12 \pm 0.04$ & $0.6 \pm 0.16$ \\
\hline$\alpha$-Cadinol & 1657 & 1652 & $2.00 \pm 0.08$ & - & $0.93 \pm 0.33$ \\
\hline Pogostol & 1660 & 1651 & - & - & $1.73 \pm 0.10$ \\
\hline trans-Calamenen-10-ol & 1671 & 1668 & - & - & $4.58 \pm 0.52$ \\
\hline Caryophyllene $<14$-hydroxy-9-epi (E)-> & 1673 & 1668 & $0.36 \pm 0.06$ & - & - \\
\hline Cadelene & 1678 & 1675 & - & - & $0.54 \pm 0.07$ \\
\hline Muskatone & 1681 & 1676 & - & - & $0.37 \pm 0.11$ \\
\hline Unidentified compound & 1685 & - & - & - & $0.75 \pm 0.17$ \\
\hline Eudesma-4 (15),7-dien- $1 \beta$-ol & 1689 & 1687 & $0.21 \pm 0.08$ & $0.33 \pm 0.27$ & - \\
\hline Unidentified Sesquiterpene & 1694 & - & - & $0.16 \pm 0.08$ & - \\
\hline Unidentified Sesquiterpene & 1707 & - & - & - & $0.28 \pm 0.06$ \\
\hline Unidentified Sesquiterpene & 1711 & - & - & $0.66 \pm 0.13$ & - \\
\hline Unidentified Sesquiterpene & 1720 & - & - & - & $0.22 \pm 0.01$ \\
\hline Unidentified Sesquiterpene & 1721 & - & - & $0.49 \pm 0.13$ & - \\
\hline Unidentified Sesquiterpene & 1728 & - & - & - & $0.51 \pm 0.06$ \\
\hline Muurolene $<14$-oxy- $\alpha>$ & 1769 & 1767 & - & - & $0.52 \pm 0.06$ \\
\hline Unidentified Sesquiterpene & 1774 & - & - & - & $0.19 \pm 0.06$ \\
\hline Methylhexadecanoate & 1926 & 1921 & - & - & $0.87 \pm 0.12$ \\
\hline Unidentified compound & 1968 & - & $0.63 \pm 0.10$ & - & - \\
\hline Total & & & 99.3 & 98.36 & 95.19 \\
\hline
\end{tabular}

${ }^{a}$ Constituents listed in order of elution on a non-polar DB-5 column. ${ }^{b}$ Retention indices (RI) calculated from retention times in relation to those of a series of $\mathrm{C}_{9}-\mathrm{C}_{30} n$-alkanes on a $30 \mathrm{~m}$ DB- 5 capillary column. ${ }^{\mathrm{c}}$ Values taken from Adams [19]. ${ }^{d}$ Value taken from Bos et al. [20].

All tested Candida species were sensitive to the essential oils and MIC values ranged from 0.625 to $1.25 \mu \mathrm{L} / \mathrm{mL}$ (Table 2). C. albicans and C. krusei were more sensitive to the $V$. guianensis oil, while C. glabrata and C. parapsilosis were more sensitive to the H. courbaril oil. All the oils showed fungicidal activity and all Candida strains were sensitive to the positive control fluconazole (Table 2). According to MFC/MIC ratios, the effect of all oils on the Candida species can be considered fungicidal.

Table 2. Minimum inhibitory concentrations (MICs) and minimal fungicidal concentrations (MFCs) on Candida species of the essential oils from leaves of $H$. courbaril var. courbaril, M. peruiferum, and $V$. guianensis as well as of positive control fluconazole.

\begin{tabular}{|c|c|c|c|c|c|c|}
\hline \multirow{2}{*}{\multicolumn{2}{|c|}{ Sample }} & \multicolumn{5}{|c|}{ Fungi } \\
\hline & & C. albicans & C. glabrata & C. krusei & C. parapsilosis & C. tropicalis \\
\hline \multirow{3}{*}{$\begin{array}{l}\text { H. courbaril } \\
\text { var. courbaril }\end{array}$} & $\operatorname{MIC}(\mu \mathrm{L} / \mathrm{mL})$ & 1.25 & 0.625 & 1.25 & 1.25 & 0.625 \\
\hline & $\operatorname{MFC}(\mu \mathrm{L} / \mathrm{mL})$ & 2.5 & 1.25 & 1.25 & 2.5 & 0.625 \\
\hline & MFC/MIC & 2 & 2 & 1 & 2 & 1 \\
\hline \multirow{3}{*}{$\begin{array}{c}\text { M. } \\
\text { peruiferum }\end{array}$} & $\mathrm{MIC}(\mu \mathrm{L} / \mathrm{mL})$ & 1.25 & 1.25 & 0.625 & 0.625 & 1.25 \\
\hline & $\operatorname{MFC}(\mu \mathrm{L} / \mathrm{mL})$ & 2.5 & 1.25 & 1.25 & 1.25 & 2.5 \\
\hline & MFC/MIC & 2 & 1 & 2 & 2 & 2 \\
\hline \multirow{3}{*}{$V \cdot$ guianensis } & $\mathrm{MIC}(\mu \mathrm{L} / \mathrm{mL})$ & 0.625 & 1.25 & 0.625 & 1.25 & 1.25 \\
\hline & $\operatorname{MFC}(\mu \mathrm{L} / \mathrm{mL})$ & 1.25 & 2.5 & 1.25 & 2.5 & 2.5 \\
\hline & MFC/MIC & 2 & 2 & 2 & 2 & 2 \\
\hline \multirow{3}{*}{ Fluconazole } & MIC $(\mu \mathrm{g} / \mathrm{mL})$ & 1.56 & 1.56 & 0.39 & 0.78 & 1.56 \\
\hline & $\operatorname{MFC}(\mu \mathrm{g} / \mathrm{mL})$ & 3.12 & 1.56 & 0.39 & 1.56 & 1.56 \\
\hline & MFC/MIC & 2 & 1 & 1 & 2 & 1 \\
\hline
\end{tabular}




\section{Discussion}

As mentioned before, mono and sesquiterpenes were the main compounds identified in the materials used in the present work, which is commonly reported for essential oils [21]. Andrade et al. [22] evaluated an essential oil from M. peruiferum bark and found a chemical composition highly distinct from that found for the leaf oil. None of the majoritary compounds of the leaf oil was present in the bark oil, and two of the major compounds of the bark oil ( $\alpha$-copaene and $\delta$-Cadinene) were detected in the leaf oil but in small concentrations. A similar situation is observed when comparing the composition of an essential oil from $H$. courbaril ripe fruit peel [23], and the leaf oil of $H$. courbaril var. courbaril that we described. The main components of the fruit oil were $\alpha$-copaene, spathulenol, and $\beta$-selinene $(11.1 \%, 10.1 \%$, and $8.2 \%$, respectively), which were only present in small concentrations in the leaf oil $(0.41 \%-1.99 \%)$.

All essential oils showed antifungal activity. The concentration range at which the essential oils were active was close to that reported for the essential oil of Myrtus communis leaves against Candida species [24]. The mechanisms of antifungal activity of essential oils seem to involve the disruption of cell membrane structure causing leakage and cell death, blocking of membrane synthesis, and cellular respiration as well as inhibition of the spore germination [25]. An essential oil from Coriandrum sativum leaves, containing the mono- and sesquiterpene hydrocarbons decanal, trans-2-decenal, 2-decen-1-ol, and cyclodecane as major compounds, was active against $C$. albicans probably by binding to the membrane ergosterol, by increasing ionic permeability, and by decreasing proteolytic activity [26]. The authors also demonstrated that this oil did not interfere with cell wall biosynthesis pathways and was most active than isolated fractions, which suggest a synergistic effect between the oil components.

The antifungal activity of $H$. courbaril var. courbaril, M. peruiferum, and V. guianensis oils can be linked to the major compounds caryophyllene oxide and trans-caryophyllene. Caryophyllene oxide was proven to be an antifungal agent against C. albicans [27], and Vieira et al. [28] showed that essential oil from Piper diospyrifolium, rich in trans-caryophyllene, was active against clinical isolates of C. albicans and C. parapsilosis. Caryophyllene oxide also showed antifungal activity against dermatophytes compared to ciclopirox olamine and sulconazole [29].

Antifungal activity has been also reported for oils containing other compounds found in the oils analyzed here. Spathulenol and bicyclogermacrene (both found in M. peruiferum oil) were the main constituents of the essential oil from leaves of Croton argyrophylloides, which was active against $C$. albicans, Candida tropicalis, and Microsporum canis [30]. An essential oil from the rhizome of Ferula hermonis containing mainly $\alpha$-pinene (also present in M. peruiferum oil) was active against Candida albicans, Candida lactis-condensi, Saccharomyces cerevisiae, Tricophyton mentagrophytes, Microsporum gypseum, Aspergillus niger, Aspergillus fumigates, and Penicillium purpurogenum [31]. The authors also reported that the compounds $\alpha$-pinene and spathulenol were active against $C$. albicans when tested separately.

\section{Conclusions}

The essential oils from three plants commonly used in Brazilian folk medicine were effective antifungal agents against Candida species. The antifungal activity of the oils is probably linked to the action of compounds such as caryophyllene oxide and trans-caryophyllene.

Acknowledgments: The authors would like to thank the Conselho Nacional de Desenvolvimento Científico e Tecnológico (CNPq; 472546/2012-0), the Coordenação de Aperfeiçoamento de Pessoal de Nível Superior (CAPES), the Fundação de Amparo à Ciência e Tecnologia do Estado de Pernambuco (FACEPE; APQ-0318-2.08/13) and the Brazilian Ministry for Science, Technology and Innovation (MCTI; 01200.003711/2011-11) for research grants. They are also grateful to the NANOBIOTEC research network CAPES for financial support.

Author Contributions: Maria da Conceição Mendes Ferreira da Costa, Alexandre Gomes da Silva, Daniela Maria do Amaral Ferraz Navarro, Márcia Vanusa da Silva, and Patrícia Maria Guedes Paiva conceived and designed the experiments; Maria da Conceição Mendes Ferreira da Costa, Alexandre Gomes da Silva, Ana Paula Sant'Anna da Silva, Patrícia Cristina Bezerra-Silva, and Suyana Karolyne Lino da Rocha performed the experiments; Maria da Conceição Mendes Ferreira da Costa, Alexandre Gomes da Silva, Patrícia Cristina Bezerra-Silva, Suyana Karolyne 
Lino da Rocha, Daniela Maria do Amaral Ferraz Navarro, Thiago Henrique Napoleão, Márcia Vanusa da Silva, and Patrícia Maria Guedes Paiva analyzed the data; Vera Lúcia de Menezes Lima, Daniela Maria do Amaral Ferraz Navarro, Maria Tereza dos Santos Correia, Márcia Vanusa da Silva, and Patrícia Maria Guedes Paiva contributed reagents/materials/analysis tools; Maria da Conceição Mendes Ferreira da Costa, Alexandre Gomes da Silva, Thiago Henrique Napoleão, Márcia Vanusa da Silva, and Patrícia Maria Guedes Paiva wrote the paper.

Conflicts of Interest: The authors declare no conflict of interest.

\section{References}

1. Coutinho, H.D.M. Factors influencing the virulence of Candida spp. West Indian Med. J. 2009, 58, 160-163. [PubMed]

2. Amaral-Lopes, S.; Moura, A. Neonatal fungal sepsis by Candida krusei: A report of three cases and a literature review. Med. Mycol. Case Rep. 2012, 1, 24-26. [CrossRef] [PubMed]

3. Ruiz, L.S.; Montelli, A.C.; Sugizaki, M.F.; Silva, E.G.; Batista, G.C.M.; Moreia, D.; Paula, C.R. Outbreak of fungemia caused by Candida parapsilosis in a neonatal intensive care unit: Molecular investigation through microsatellite analysis. Rev. Iberoam. Micol. 2013, 30, 112-115. [CrossRef] [PubMed]

4. Guo, Y.; Wang, P.; Lu, L.; Xia, S.; Shen, W. Rare appearance of Candida tropicalis infection of the brain: Multiple micro-abscesses combined with diffuse hemorrhages. Radiol. Infect. Dis. 2014, 1, 33-36. [CrossRef]

5. Vermitsky, J.P.; Edlind, T.D. Azole resistance in Candida glabrata: Coordinate upregulation of multidrug transporters and evidence for a Pdr1like transcription factor. Antimicrob. Agents Chemother. 2004, 48, 377-381. [CrossRef] [PubMed]

6. Pfaller, M.A.; Diekema, D.J.; Gibbs, D.L.; Newell, V.A.; Nagy, E.; Dobiasova, S.; Rinaldi, M.; Barton, R.; Veselov, A. Candida krusei, a multidrug-resistant opportunistic fungal pathogen: Geographic and temporal trends from the ARTEMIS DISK Antifungal Surveillance Program, 2001 to 2005. J. Clin. Microbiol. 2008, 46, 515-521. [CrossRef] [PubMed]

7. Morace, G.; Perdoni, F.; Borghi, E. Antifungal drug resistance in Candida species. J. Glob. Antimicrob. Resist. 2014, 2, 254-259. [CrossRef] [PubMed]

8. Matos, F.J.A. Farmácias Vivas: Sistema de Utilização de Plantas Medicinais Projetado para Pequenas Comunidades; Editora da UFC: Fortaleza, Brazil, 2002.

9. Laird, K.; Philips, C. Vapour phase: A potential future use for essential oils as antimicrobials? Lett. Appl. Microbiol. 2011, 54, 169-174. [CrossRef] [PubMed]

10. Soares, I.H.; Loreo, E.S.; Rossato, L.; Mario, D.N.; Venturini, T.P.; Baldissera, F.; Santurio, J.M.; Alves, S.H. In vitro activity of essential oils extracted from condiments against fluconazole-resistant and -sensitive Candida glabrata. J. Med. Mycol. 2015, 25, 213-217. [CrossRef] [PubMed]

11. Abad, M.J.; Bedoya, L.M.; Apaza, L.; Bermejo, P. The Artemisia L. genus: A review of bioactive essential oils. Molecules 2012, 17, 2542-2566. [CrossRef] [PubMed]

12. Agra, M.F.; Silva, K.N.; Basílio, J.L.D.; Freitas, P.F.; Barbosa-Filho, J.M. Survey of medicinal plants used in the region Northeast of Brazil. Rev. Bras. Farmacogn. 2008, 18, 472-508. [CrossRef]

13. Agra, M.F.; Freitas, P.F.; Barbosa-Filho, J.M. Synopsis of the plants known as medicinal and poisonous in Northeast of Brazil. Rev. Bras. Farmacogn. 2007, 17, 114-140. [CrossRef]

14. Bezerra, G.P.; Góis, R.W.S.; Brito, T.S.; Lima, F.J.B.; Bandeira, M.A.M.; Romero, N.R.; Magalhães, P.J.C.; Santiago, G.M.P. Phytochemical study guided by the myorelaxant activity of the crude extract, fractions and constituent from stem bark of Hymenaea courbaril L. J. Ethnopharmacol. 2013, 149, 62-69. [CrossRef] [PubMed]

15. Muñoz, V.; Sauvain, M.; Bourdy, G.; Arrázola, S.; Callapa, J.; Ruiz, G.; Choque, J.; Deharo, E. A search for natural bioactive compounds in Bolivia through a multidisciplinary approach Part III. Evaluation of the antimalarial activity of plants used by Alteños Indians. J. Ethnopharmacol. 2000, 71, 123-131. [CrossRef]

16. Trenti, D.S.; Giordani, R.B.; Zimmer, K.R.; Silva, A.G.; Silva, M.V.; Correia, M.T.S.; Baumvol, I.J.R.; Macedo, A.J.M. Potential of medicinal plants from the Brazilian semi-arid region (Caatinga) against Staphylococcus epidermidis planktonic and biofilm lifestyles. J. Ethnopharmacol. 2011, 137, 327-335. [CrossRef] [PubMed]

17. Albuquerque, U.P.; Monteiro, J.M.; Ramos, M.A.; Amorim, E.L.C. Medicinal and magic plants from a public market in northeastern Brazil. J. Ethnopharmacol. 2007, 110, 76-91. [CrossRef] [PubMed]

18. Van den Dool, H.; Kratz, D.J. A generalization of the retention index system including linear temperature programmed gas-liquid partition chromatography. J. Chromatogr. 1963, 11, 463-467. [CrossRef] 
19. Adams, R.P. Identification of Essential Oil Components by Gas Chromatography/Mass Spectrometry, 4th ed.; Allured Publishing Co.: Carol Stream, IL, USA, 2009.

20. Bos, R.; Stojanova, A.S.; Woerdenbag, H.J.; Koulman, A.; Quax, W.J. Volatile components of the aerial parts of Artemisia pontica L. grown in Bulgaria. Flav. Fragr. J. 2005, 20, 145-148. [CrossRef]

21. Perricone, M.; Arace, E.; Corbo, M.R.; Sinigaglia, M.; Bevilacqua, A. Bioactivity of essential oils: A review on their interaction with food components. Front. Microbiol. 2015, 6, 76. [CrossRef] [PubMed]

22. Andrade, M.A.; Azevedo, C.S.; Motta, F.N.; Santos, M.L.; Silva, C.L.; Santana, J.M.; Bastos, I.M.D. Essential oils: In vitro activity against Leishmania amazonensis, cytotoxicity and chemical composition. BMC Complement. Altern. Med. 2016, 16, 444. [CrossRef] [PubMed]

23. Aguiar, J.C.; Santiago, G.M.; Lavor, P.L.; Veras, H.N.; Ferreira, Y.S.; Lima, M.A.; Arriaga, A.M.; Lemos, T.L.; Lima, J.Q.; Jesus, H.C.; et al. Chemical constituents and larvicidal activity of Hymenaea courbaril fruit peel. Nat. Prod. Commun. 2010, 5, 1977-1980. [PubMed]

24. Cannas, S.; Molicotti, P.; Ruggeri, M.; Cubeddu, M.; Sanguinetti, M.; Marongiu, B.; Zanetti, S. (2013) Antimycotic activity of Myrtus communis L. towards Candida spp. from clinical isolates. J. Infect. Dev. Countr. 2013, 7, 295-298.

25. Harris, R. Progress with superficial mycoses using essential oils. Int. J. Aromather. 2002, 12, 83-91. [CrossRef]

26. Freires, I.A.; Murta, R.M.; Furletti, V.F.; Sartoratto, A.; Alencar, S.M.; Figueira, G.M.; Rodrigues, J.A.O.; Duarte, M.C.T.; Rosalen, P.L. Coriandrum sativum L. (Coriander) essential oil: Antifungal activity and mode of action on Candida spp., and molecular targets affected in human whole-genome expression. PLoS ONE 2014, 9. [CrossRef] [PubMed]

27. Schmidt, E.; Bail, S.; Friedl, S.M.; Jirovetz, L.; Buchbauer, G.; Wanner, J.; Denkova, Z.; Slavchev, A.; Stoyanova, A.; Geissler, M. Antimicrobial activities of single aroma compounds. Nat. Prod. Commun. 2010, 5, 1365-1368. [PubMed]

28. Vieira, S.C.H.; Paulo, L.F.; Svidzinski, T.I.E.; Dias Filho, B.P.; Nakamura, C.V.; Souza, A.; Young, M.C.M.; Cortez, D.A.G. Antifungal activity of Piper diospyrifolium Kunth (Piperaceae) essential oil. Braz. J. Microbiol. 2011, 42, 1001-1006. [CrossRef] [PubMed]

29. Yang, D.; Michel, L.; Chaumont, J.P.; Millet-Clerc, J. Use of caryophyllene oxide as an antifungal agent in an in vitro experimental model of onychomycosis. Mycopathologia 1999, 148, 79-82. [CrossRef] [PubMed]

30. Fontenelle, R.O.; Morais, S.M.; Brito, E.H.; Brilhante, R.S.; Cordeiro, R.A.; Nascimento, N.R.; Kerntopf, M.R.; Sidrim, J.J.; Rocha, M.F. Antifungal activity of essential oils of Croton species from the Brazilian Caatinga biome. J. Appl. Microbiol. 2008, 104, 1383-1390. [CrossRef] [PubMed]

31. Al-Ja'fari, A.-H.; Vila, R.; Freixa, B.; Tomi, F.; Casanova, J.; Costa, J.; Cañigueral, S. Composition and antifungal activity of the essential oil from the rhizome and roots of Ferula hermonis. Phytochemistry 2011, 72, 1406-1413. [CrossRef] [PubMed]

(C) 2017 by the authors. Licensee MDPI, Basel, Switzerland. This article is an open access article distributed under the terms and conditions of the Creative Commons Attribution (CC BY) license (http://creativecommons.org/licenses/by/4.0/). 